\title{
TINJAUAN KRITIS TERHADAP TEORI AKTIVITAS DAN DILEMA SOSIAL
}

\author{
Juneman \\ Jurusan Psikologi, Fakultas Psikologi, Bina Nusantara University \\ Jl. Kemanggisan Ilir III No. 45, Kemanggisan, Palmerah, Jakarta Barat 11480 \\ Juneman@binus.ac.id
}

\begin{abstract}
Nowadays, there are developing theories in social psychology. Two of them are activity and social dilemma theory. Unfortunately, Indonesia has less expertise in specific theoretical social psychology. The article is purposed to give analysis for the two theories including its history, its development today, and also its research critical and prospect in the future. This description could help academics and practitioners to build and develop best theories (as well as practice) in their own environment. Based on the critical analysis, it could be concluded that along with their advantages and limits, both activity and social dilemma theory are prospective in triggering researches especially in Indonesia, where there are not much research using those theories.
\end{abstract}

Keywords: activity theory, social dilemma, social psychology

\begin{abstract}
ABSTRAK
Dewasa ini di dunia berkembang pesat sejumlah teori dalam lingkup psikologi sosial. Dua di antaranya adalah teori aktivitas dan dilema sosial. Sayangnya, di Indonesia kepakaran dalam bidang-bidang teoritis spesifik psikologi sosial tersebut belum banyak dibangun. Tulisan ini ditujukan untuk memberikan tinjauan tentang kedua teori tersebut mulai dari sejarah, perkembangannya dewasa ini, sampai dengan kritik dan prospek riset di masa mendatang. Uraian ini dapat membantu akademisi dan praktisi untuk membangun dan mengembangkan teori (demikian juga praktik) terbaik di lingkungan masing-masing. Dari kajian kritis dapat disimpulkan bahwa dengan berbagai kelebihan dan keterbatasannya, baik teori aktivitas maupun dilema sosial itu prospektif dalam hal merangsang riset khususnya untuk kasus-kasus di Indonesia, karena belum banyak yang melakukan penggarapan dengan menggunakan analisis kedua teori tersebut.
\end{abstract}

Kata kunci: teori aktivitas, dilema sosial, psikologi sosial 


\section{PENDAHULUAN}

Dewasa ini di dunia berkembang pesat sejumlah teori dalam lingkup psikologi sosial, baik teori berskala besar maupun berskala mini. Dua di antaranya adalah teori aktivitas dan dilema sosial. Sayangnya, khususnya di Indonesia, kepakaran dalam bidang-bidang teoritis spesifik psikologi sosial tersebut belum banyak dibangun. Tulisan ini ditujukan untuk memberikan tinjauan tentang kedua teori tersebut mulai dari sejarah, perkembangannya dewasa ini, sampai dengan kritik dan prospek riset di masa mendatang.

\section{PEMBAHASAN}

\section{Teori Aktivitas}

Teori aktivitas (activity theory) merupakan sebutan ringkas dari Cultural-Activity Theory (CHAT). Perspektif teoretis CHAT menekankan interdependensi kultural dan kontekstual antara aktivitas dan mind manusia. Fondasi teoretis dari teori aktivitas (Engeström, 1987) dapat ditemukan dalam: (1) akar filosofis Marx (transformasi sosietal); (2) semiotika C. S. Peirce (tanda, makna, pengetahuan); (3) sosiologi/psikologi sosial G. H. Mead dan Colwyn Trevarthen (intersubjektivitas, perkembangan bahasa); dan (4) psikologi Rusia Lev Vygotsky, Alexey Leontyev, dan Alexander R. Luria (learning \& development dalam teori aktivitas).

Pertanyaan utama teori aktivitas setidaknya ada dua. Pertama, bernada psikologis, bagaimanakah memahami pengamatan kita tentang tindakan manusia secara bermakna? Kedua, pertanyaan itu berbunyi: Dapatkah teori aktivitas mengembangkan sebuah sistem yang mengatur diri sendiri (self-organizing system) mengenai interaksi subjek? Dalam hal ini terdapat ketegangan antar dua kekuatan/arah/perkembangan. Satu kekuatan menarik para peneliti pada aplikasi individual. Kekuatan yang lain menarik peneliti pada kontestasi gagasan dan aplikasi satu orang dengan yang lainnya. Konsekuensinya, pertanyaan ini menjadi: dapatkah kita memiliki pengertian bersama yang memadai tentang ide aktivitas sehingga menjadi teori aktivitas yang evolusioner dan multi-perspektif (Engeström, 1999).

Tujuan utama penelitian teori aktivitas setidaknya ada tiga. Pertama, melampaui dualisme (transcending the dualisms), yakni dualisme antara pikiran (thought) dan aktivitas, teori dan praktik, fakta dan nilai (Engeström, 1999). Kedua, mengintegrasikan pendekatan aktivitas dengan pendekatan naturalistik dalam kerangka kerja yang koheren (Bedny \& Karwowski, 2004). Contoh pendekatan naturalistik adalah pemrosesan informasi (human information processing), sebuah paradigma dominan dalam psikologi kognitif. Pendekatan kognitif umumnya dirumuskan sehubungan dengan asumsiasumsi mentalistik artifisial, yang telah mengeliminasi interkoneksi mind dengan dunia melalui mediated activity. Kelemahan utama dari pendekatan naturalistik adalah kegagalannya dalam mengapresiasi bahwa pengetahuan manusia mengenai dunia eksternal dalam derajat tertentu bersifat intersubjektif (Vygotsky, 1978) dan dimediasikan oleh aktivitas manusia. Tujuan ketiga adalah menghubungkan studi-studi mikro (microstudies) tentang tindakan, interaksi, dan pengetahuan dengan teori-teori makro (macrotheories) tentang institusi sosial dan struktur masyarakat. Teori aktivitas dengan pendekatan jejaring sosial-nya mampu menjembatani kedua studi tersebut (Engeström, 1999).

Metode penelitian yang umum digunakan dalam riset-riset teori aktivitas adalah metode analitik yang ketat (rigorous analyses) terhadap sistem aktivitas. Checkland \& Scholes (dalam Avis, 2007) mendeskripsikan metode teori aktivitas ini sebagai berikut: Carilah sebuah situasi dalam dunia riil yang telah merangsang konsen; pilih sejumlah sistem aktivitas; buatlah model tentangnya; gunakan model-model untuk mempertanyakan situasi dunia nyata dalam sebuah fase komparasi; gunakan debat yang dimulai dalam tahap komparasi untuk mendefinisikan tindakan bertujuan (purposeful action) 
yang dapat meningkatkan mutu situasi problem awal. Pengambilan tindakan akan mengubah situasi, sehingga keseluruhan siklus akan mulai bergerak kembali. Metodologi ini dikenal sebagai expansive methodology (Engeström, 1987), atau pun formative experiment (Van Oers, Elbers, Van der Veer \& Wardekker, 2008) yang mengombinasikan partisipasi aktif peneliti dengan pemantauan (monitoring) terhadap perubahan perkembangan dari objek studi (developmental work research/DWR). Penelitianpenelitian yang seringkali menggunakan metode analitis dengan model segitiga sistem aktivitas.

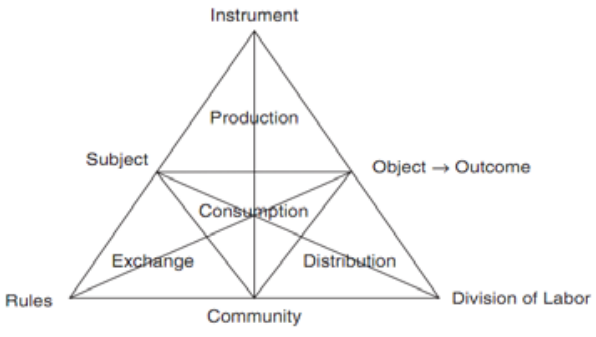

Gambar 1a Model sistem aktivitas Sumber: Håkansson \& Prenkert (2004)

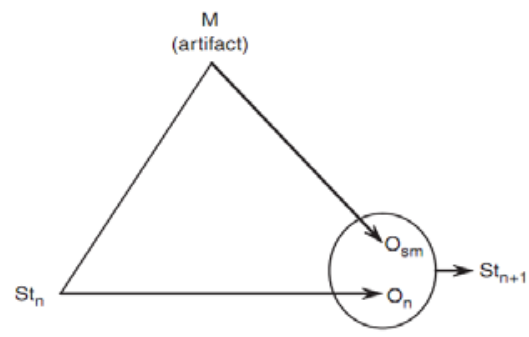

Gambar 1b Segitiga dasar Sumber: Cole \& Engeström (1993)

Penjelasan: Gambar 1a, segitiga atas. Model aktivitas memiliki basis perspektif Vygotskian tentang interaksi yang dimediasikan perangkat (tool/instrument-mediated interaction) antara subjek dan objek [Gegenstand]. Model ini merepresentasikan interaksi manusia dan mengakui bahwa interaksi ini dimediasikan oleh artifak-artifak. Mediating artifacts ini adalah perangkat (tools), tandatanda (signs), dan peralatan (instruments)—baik yang merupakan alat-alat eksternal (external implements) maupun representasi internal (internal representations; seperti model-model mental) yang digunakan oleh subjek untuk berinteraksi dengan objek (Engeström, 1999).

Virkkunen \& Kuutti (2000) dengan meminjam konseptualisasi Cole dan Engeström (1993) memberikan contoh sebagai berikut (Gambar 1 b merupakan unsur segitiga dasar dari model 1a-atas):

Seorang pasien datang ke dokter. Dokter mempersepsikan penampilan pasien tersebut. Ketika memeriksa pasien, sang dokter memperoleh persepsi yang lebih langsung (garis S-O dalam Gambar 1b; S adalah dokter dan O adalah pasien; garis S-O merepresentasikan fungsi-fungsi alamiah/natural, tak dimediasikan/unmediated). Di samping itu, sang dokter menggunakan konsep-konsep, teori-teori, dan kategori-kategori penyakit dari ilmu kedokteran. Sang dokter juga menggunakan serangkaian metode penelitian dan instrumen ketika meneliti pasien. Persepsi segera sang dokter (immediate perceptions; persepsi ketika dokter berhadapan langsung dengan pasien) berkoordinasi dengan persepsi sangat dokter yang diciptakan melalui mediasi artifak-artifak (konsep, kategori, metode, dan sebagainya). Bentuk koordinasi ini (garis $\mathrm{St}_{\mathrm{n}}-\mathrm{M}-\mathrm{O}$ ) misalnya adalah pengukuran tekanan darah, yang membuat dokter menghasilkan diagnosis mengenai penyakit pasien dan gambaran posibilitas pengobatannya $\left(\mathrm{St}_{\mathrm{n}+1}\right) . \mathrm{St}_{\mathrm{n}}$ adalah kondisi pengetahuan Subjek pada waktu $n . \mathrm{O}_{\mathrm{sm}}$ adalah Objek sebagaimana direpresentasikan melalui Medium. $\mathrm{O}_{\mathrm{n}}$ adalah Objek pada waktu $n$. $\mathrm{St}_{\mathrm{n}+1}$ merupakan kondisi baru yang dihasilkan dari pengetahuan subjek pada waktu $n+1$.

Sebuah artifak dapat berupa benda-benda material yang nyata maupun sesuatu yang sama sekali tak teraba (totally intangible). Artifak dapat digunakan dalam cara-cara yang variatif.

Gambar 1a, segitiga-segitiga bawah. Sebagaimana dikemukakan sebelumnya, relasi antara subjek dan objek dimediasikan melalui artifak-artifak kultural dan material, dalam hal ini perangkat dan instrumen. Namun relasi itu juga selalu disituasikan dalam sebuah konteks sosial dari praktik manusia. Subjek berelasi dengan sebuah komunitas kolektif; relasi ini dimediasikan pula sebagaimana relasi antara subjek dan objek. Namun, interaksi antara subjek dan komunitas dimediasikan tidak 
hanya melalui artifak-artifak kultural, melainkan juga melalui aturan-aturan (rules) dan division of labor, sebagaimana segitiga-segitiga bawah pada Gambar 1a (Virkkunen \& Kuutti, 2000). Rules menentukan interaksi-interaksi yang dapat diterima (acceptable) antar anggota komunitas. Division of labor merupakan distribusi tugas, kekuasaan, dan tanggungjawab yang dinegosiasikan secara berkesinambungan antar partisipan sistem aktivitas.

Jadi, sistem aktivitas dapat dispesifikasikan dalam bagian-bagian, yakni (1) tindakan terdekontekstualisasi (decontextualized action) segitiga atas; dan (2) aktivitas kolektif terkontekstualisasi (contextualized collective activity). Aktivitas kolektif terkontekstualisasi (atau, ringkasnya disebut: aktivitas) merupakan keseluruhan sistem aktivitas yang mencakup segitiga atas yang dilengkapi dengan segitiga-segitiga bawah. Konsep aktivitas dikembangkan Engeström dari gagasan Leontyev (1977), yang membedakan antara aktivitas (yang didorong motif, diorientasikan pada objek/gegenstand), tindakan (sadar, didorong tujuan, milestone dari aktivitas), dan operasi (tak sadar, terutinkan). Tindakan individual baru dapat dimaknai penuh apabila unit analisisnya sistem aktivitas berorientasi objek (object oriented activity system).

Pertanyaan yang sering muncul dalam jurnal ilmiah terkait teori aktivitas dewasa ini adalah bagaimanakah teori aktivitas dapat diaplikasikan/dipraktikkan pada penelitian yang sedang dilakukan? Hasil utama berbagai studi teori aktivitas dapat diringkaskan setidaknya dalam tiga hal. Pertama, penelitian ini telah memberikan perbendaharaan pengetahuan untuk memahami situasi masalah dalam cara-cara yang baru. Kedua, membantu para pemangku kepentingan untuk memfasilitasi strategi penciptaan dan pemeliharaan aktivitas-aktivitas yang perlu dengan memperhatikan kontradiksi atau tensi yang ada dalam sistem aktivitas. Ketiga, riset teori aktivitas telah mentransformasikan prosesproses interaksi antar-aktivitas secara kreatif dengan mempertimbangkan aspek-aspek sosio-historis dari sistem aktivitas lain, baik di dalam maupun di luar organisasi (seperti perusahaan, dan sebagainya).

Hal menarik dari berbagai studi teori aktivitas adalah bahwa teori ini menawarkan alternatif teoritis baru yang tidak mengandalkan (bahkan: menolak) asumsi psikologi Barat, yang menyatakan bahwa individu merupakan entitas tersendiri yang menyusun titik awal dari setiap penjelasan tentang pengetahuan dan praktik manusia. Insight baru yang diperoleh dari teori aktivitas adalah bahwa individu dan kolektivitas-sosial hanya dapat dimengerti secara dialektis, historis, dalam relasi satu dengan yang lain. Daya tarik teori ini yang lain juga adalah penjelasannya yang tidak mengandalkan penjelasan relasi kausal masukan (inputs) dan keluaran (outputs) sebagaimana banyak diasumsikan oleh Psikologi Industri dan Organisasi dari Barat. Sebagaimana dikemukakan pada awal tulisan ini, teori aktivitas justru banyak meneliti self-organization dari sebuah sistem aktivitas. Capra (2002) menjelaskan analogi kualitas self-regulation dari sebuah sistem kompleks, bahwa menendang sebuah batu berbeda dengan menendang seekor anjing. Menendang batu dapat dijelaskan secara linear dengan mekanika Newton, sedangkan anjing yang ditendang akan merespons sesuai dengan perubahan struktural seturut natur dan pola-pola organisasi tindakan nonlinear-nya sendiri. Implikasinya, sebagaimana ditegaskan Toulmin (1999), bahwa guna memahami sistem aktivitas tertentu, peneliti harus mengotori tangannya dengan menghimpun deskripsi-deskripsi terinci mengenai prosedurprosedur atau sekuens-sekuens aksi yang menjadi karakter dari sistem aktivitas tersebut. Peneliti tidak boleh terlepas (detached) dari aktivitas orang-orang dalam sistem tersebut.

Di samping itu, berdasarkan studi-studi yang ada, didapati bahwa teori aktivitas sangat menghargai diversitas dan pluralitas. Hal ini nampak dari penekanan teori aktivitas bahwa meskipun sejumlah subjek berada pada sistem aktivitas yang sama, dan mereka saling bergantung, namun mereka dapat berbeda secara signifikan dalam pemahaman mereka mengenai objek dan aspek-aspek lain dari sistem aktivitas seiring dengan perbedaan historisitas dan posisi subjek. Apresiasi terhadap keberagamaan ini memiliki implikasi praktis yang penting khususnya di Indonesia yang ke-Bhinneka Tunggal Ika-annya terus terancam dengan upaya sebagian pihak meminggirkan mereka yang berbeda (“Penyeragaman yang Menyusup”, 2010). 
Secara metodologis, sejumlah studi yang ada tentang teori aktivitas belum banyak memperlihatkan secara jelas bagaimana sistem aktivitas diteliti sebagai sebuah integritas, bukan hanya sebuah agregat individual yang menyusunnya. Hal ini penting karena Engeström \& Miettinen (1999) menyatakan bahwa praktik kolektif tidak dapat direduksikan pada penjumlahan tindakan individual melainkan membutuhkan konseptualisasi teoretis mengenai natur praktik kolektif tersebut. Gagasan ini dapat dirunut dari Psikologi Gestalt dan pemikiran Ilyenkov bahwa totalitas konkret tidak dapat direduksi pada bagian-bagiannya, karena bagian-bagian itu justru memperoleh arti pentingnya dari posisi/tempatnya dalam keseluruhan (Bakhurst, 1991). Sayangnya, studi-studi yang ada belum banyak yang berhasil menunjukkan secara empiris bagaimana konsep Gestalt sistem aktivitas ini terjadi di lapangan kehidupan nyata, terlebih lagi untuk kasus-kasus di Indonesia. Banyak laporan penelitian tentang teori aktivitas yang nampaknya masih menggunakan diskusi filosofis dan spekulatif. Padahal teori aktivitas diklaim sebagai (kontribusi) psikologi-nya Rusia. Psikologi adalah sebuah ilmu yang membutuhkan penjelasan empiris. Teori dalam psikologi juga harus memiliki kekuatan prediktif, bukan hanya model/skema analitis. Banyak studi yang mengaplikasikan begitu saja (meskipun dengan keketatan/rigorousness) prinsip-prinsip dan hukum-hukum sistem aktivitas. Ini merupakan kelemahan dari banyak studi yang ada yang menggunakan teori aktivitas. Hal yang demikian ini hanya akan tiba pada kesimpulan yang standar dan terburu-buru mengenai sistem aktivitas yang diteliti.

Manusia terlibat dalam sejumlah besar aktivitas (makan, bermain, berpikir, berimajinasi, berkelahi, dan sebagainya). Sejumlah aktivitas ini memang memunculkan pertanyaan filosofis dan psikologis yang penting. Namun, sejumlah lagi mungkin tidak. Kritik berdasarkan premis di atas adalah: Apa yang mendasari pentingnya (apa yang kita peroleh dari) penggolongan semua aktivitas tersebut dalam sebuah kategori tunggal bernama aktivitas? Pertanyaan ini semakin menekan bila kita berfokus pada aktivitas-aktivitas yang lebih konkret, seperti mengobati pasien yang menderita skizofrenia, mengajari anak kecil tata bahasa dari bahasa ibunya, perang peretas komputer IndonesiaMalaysia, memvonis kejahatan korupsi. Penelitian psikologis mungkin berguna dalam menjawab sejumlah aspek dari hal-hal tersebut. Namun bagaimana mungkin cukup dengan sebuah teori sistem aktivitas saja?

Selanjutnya, sudah sejak tahun 1890, William James dalam buku klasiknya, Principles of Psychology mengemukakan konsep Ego murni (pure Ego). Ego murni merupakan perasaan kesamaan (feeling of sameness) yang meresapi seluruh episode kehidupan seseorang, sehingga orang dapat mengatakan bahwa "Saya adalah diri yang sama dengan diri saya kemarin" (I am the same self that I was yesterday) (James, 1890). Ego murni memuat perasaan akan identitas pribadi (sense of personal identity), yakni pemikiran dan perasaan yang membawa semua hal secara bersama-sama menjadi objek dari penilaian tunggal (single judgment). Sementara itu, Engeström (2001) menjelaskan bahwa orang selalu berada dalam keadaan berbeda sebagai hasil dari posisinya yang berbeda dalam sistem. Bila mengikuti alur pikir Engeström, maka ketika penulis bergerak dari suatu kampus menuju halte busway, penulis bukan "Juneman” yang sama lagi. Tidak ada kontinuitas dari diri (self-continuance), tidak ada pure Ego, karena penulis sudah berelasi dengan division of labor yang berbeda.

Terminologi objek aktivitas [Gegenstand] juga mengandung makna yang ambigu untuk sebuah sains/teori. Dalam satu interpretasi yang paling natural, Gegenstand dimaknai sebagai tujuan aktivitas. Contoh: objek dari tindakan saya menulis artikel ini adalah untuk memperoleh pemahaman yang lebih jelas mengenai status saat ini, kelebihan-kelemahan, serta prospek riset masa depan dari teori aktivitas. Interpretasi yang lain dari Gegenstand adalah sesuatu terhadap apa subjek melakukan. Dalam bidang material, hal ini jelas. Gegenstand dari pedagang adalah barang dagangan. Objek dari penulis artikel ini adalah teori aktivitas. Objek juga dapat diinterpretasikan dengan mengetahui apa yang hendak dicapai oleh subjek, dan ini sangat abstrak atau ill-defined questions dalam terminologi pemecahan masalah. Jadi kalau orang ditanya, “Apakah objek dari gerakan reformasi di Indonesia?” kita hanya dapat menjawabnya dengan menjawab terlebih dahulu pertanyaan, "Apakah yang ingin dicapai oleh gerakan reformasi?”, “Apa yang para 'reformis' pikirkan pada waktu mereka melakukannya, misalnya di tahun 1998?”. Tetapi, lagi-lagi, kita juga bisa menjawab pertanyaan 
tersebut dengan memberikan jawaban "hukum”, “ekonomi”, “ABRI”, dan sebagainya. Hal ini membuat sulit untuk memahami teori aktivitas sebagai sebuah teori dan bukan filosofi, terutama bagi orang awam.

Penelitian selanjutnya perlu melakukan lebih banyak studi-studi teori aktivitas kualitatifempiris yang menggunakan metode hermeneutik dan naratif. Hal ini juga harus ditunjang dengan penyelenggaraan studi-studi longitudinal yang jauh lebih banyak dan intensif. Usulan ini guna menghindari pragmatisme dalam riset, namun temuannya akan jauh lebih bermakna. Bahkan, lebih baik lagi bila studi-studi teori aktivitas dilengkapi dengan studi-studi dari disiplin lain, tidak hanya monolotik; seperti misalnya studi tentang arketip, ilmu pemerintahan, bisnis, dan lain-lain. Hal ini karena studi monolitik saja tidak memadai. Penelitian selanjutnya juga perlu menjawab pertanyaan, “Apakah sistem aktivitas dapat diidentifikasikan sebagai pengetahu kolektif (collective knower)?” Hal ini masih problematik dalam activity theory. Memang, Engeström mengakui bahwa pembelajaran (learning), sebagai fenomena yang banyak diteliti oleh teori aktivitas, dapat mengambil tempat pada level sistem, sebagaimana terdapat dalam konsep pembelajaran ekspansif (Engeström, 2001) yang terwujudkan dalam ola aktivitas yang baru secara kultural. Namun teori aktivitas masih segan memposisikan eksistensi dari pengetahu kolektif sebagai subjek kolektif. Apakah subjek kolektif itu ada dalam sebuah sistem aktivitas yang dalam activity theory mengasumsikan desentralisasi sistem?

Di samping itu, penelitian mendatang perlu menentukan Seberapa jauh kontribusi pengetahuan individu unik dalam sebuah sistem aktivitas. Sebagaimana kita ketahui, proses dialektis antara subjek dan masyarakat berimplikasi pada proposisi teori aktivitas bahwa semua pengetahuan manusia dimediasikan oleh aktivitas sosial, oleh perangkat kultural. Namun, pertanyaannya kemudian adalah: Apakah pengetahuan unik yang berasal dari individu sungguh-sungguh tidak ada? Apabila ada, sejauh mana peran atau kontribusinya? Pertanyaan ini menjadi relevan karena manusia bukan hanya berada dalam sebuah konteks sosial, tetapi juga memiliki sistem fisis, biologis, dan ketubuhan yang mungkin independen terhadap mediasi kultural. Bagaimana sistem fisis dan biologis ini harus dipandang?

Selanjutnya, studi-studi yang ada juga belum banyak menjawab pertanyaan "Apakah yang terjadi apabila ada dua sistem aktivitas atau lebih yang tidak hanya berelasi, tetapi juga tumpang tindih?” Engeström (2001) memang menyatakan bahwa dua sistem aktivitas yang terpisah, dengan objek-objek dan aktivitas yang berbeda, dapat berkolaborasi bersama untuk mengkonstruksi sebuah objek bersama yang baru yang melampaui atau mengembangkan objek-objek sebelumnya. Namun pertanyaannya adalah: Apakah dua sistem aktivitas tersebut melebur menjadi satu sistem aktivitas yang lebih besar, dan objek/gegenstand yang baru mencaplok objek-objek yang lama? Ataukah, dua atau lebih sistem aktivitas itu tetap eksis sebagai sistem yang berbeda namun memiliki level sistem yang berbeda (ada sistem dalam sistem)? Bila iya, bagaimana relasi ketersarangan (nestedness) ini?

\section{Dilema Sosial}

Dilema sosial merupakan situasi-situasi dalam mana setiap anggota dari sebuah kelompok memiliki insentif yang jelas dan tidak ambigu untuk sebuah pilihan yang —-ketika pilihan itu dipilih oleh semua individu anggota kelompok - memberikan hasil yang lebih buruk bagi semua ketimbang yang akan mereka terima apabila tidak seorang pun dari mereka memilih pilihan tersebut. Apabila orang menyangkal keuntungan segera (immediate benefit) untuk masing-masing dirinya, justru hal ini menghasilkan kebaikan bersama khususnya dalam jangka panjang (collective interest) (Weiten, 1989). Contoh yang paling dikenal adalah dilema terdakwa (prisnoers’ dilemma) (Sarwono, 2005):

Dalam teori dilema terdakwa, diandaikan ada dua orang terdakwa yang sedang diperiksa oleh jaksa. Jaksa memberi tahu tentang konsekuensinya kalau mereka mengaku atau tidak mengaku. Kalau terdakwa A mengaku sedangkan terdakwa B tidak mengaku, A dapat 
dihukum 10 tahun penjara sedangkan B bebas. Akan tetapi, kalau A mengaku sementara B juga mengaku, keduanya hanya mendapat hukuman masing-masing satu tahun penjara.

Sebaliknyam kalau ada tidak mengaku dan B mengaku, B lah yang mendapat hukuman 10 tahun sedangkan A bebas. Sebaliknya, kalau kedua-duanya tidak mengaku, A dan B samasama mendapat hukuman 5 tahun penjara. Menghadapi kemungkinan-kemungkinan di atas, seharusnya kedua terdakwa sama-sama mengaku saja agar mereka sama-sama mendapat hukuman yang paling ringan. Akan tetapi, kalau terdakwa diperiksa dan tidak dapat saling berunding, kecenderungannya adalah bahwa mereka sama-sama tidak mau mengaku karena keduanya berpikir bahwa kalau hanya ia sendiri yang mengaku, ia akan mendapat hukuman paling berat sementara temannya akan bebas. Akibatnya, kedua terdakwa itu mendapat hukuman 5 tahun penjara (p. 131).

Pertanyaan utama yang hendak dijawab oleh penelitian dilema sosial adalah: "Bagaimanakah menjelaskan pengambilan keputusan dalam situasi-situasi sosial yang dilematis yang bervariasi dan kompleks?" dan "Faktor-faktor apa sajakah yang mampu memprediksi tingkat pilihan yang mengutamakan diri sendiri dan tingkat pilihan yang mengutamakan/menguntungkan kelompok, serta dalam situasi yang bagaimana?” (Dawes \& Messick, 2000). Jadi, tujuan utama penelitian dilema sosial adalah menghasilkan teori psikologis yang mampu menjawab pertanyaan tersebut, dengan ketentuan bahwa teori tersebut harus cukup fleksibel untuk diaplikasikan dalam konteks yang luas dan bervariasi, serta harus cukup konkret untuk membuat prediksi, dan validitasnya dapat diperiksa. Pertanyaan yang muncul dalam studi-studi tentang dilema sosial adalah pertanyaan-pertanyaan yang menyangkut masalah jenis-jenis dilema sosial, sebagaimana nampak pada skema dalam Gambar 1. Inti dari skema pada Gambar 1 adalah bahwa terdapat taksonomi dalam riset-riset dilema sosial. Kemajuan riset dilema sosial diukur dari sejauh mana taksonomi ini dikukuhkan atau diperluas.

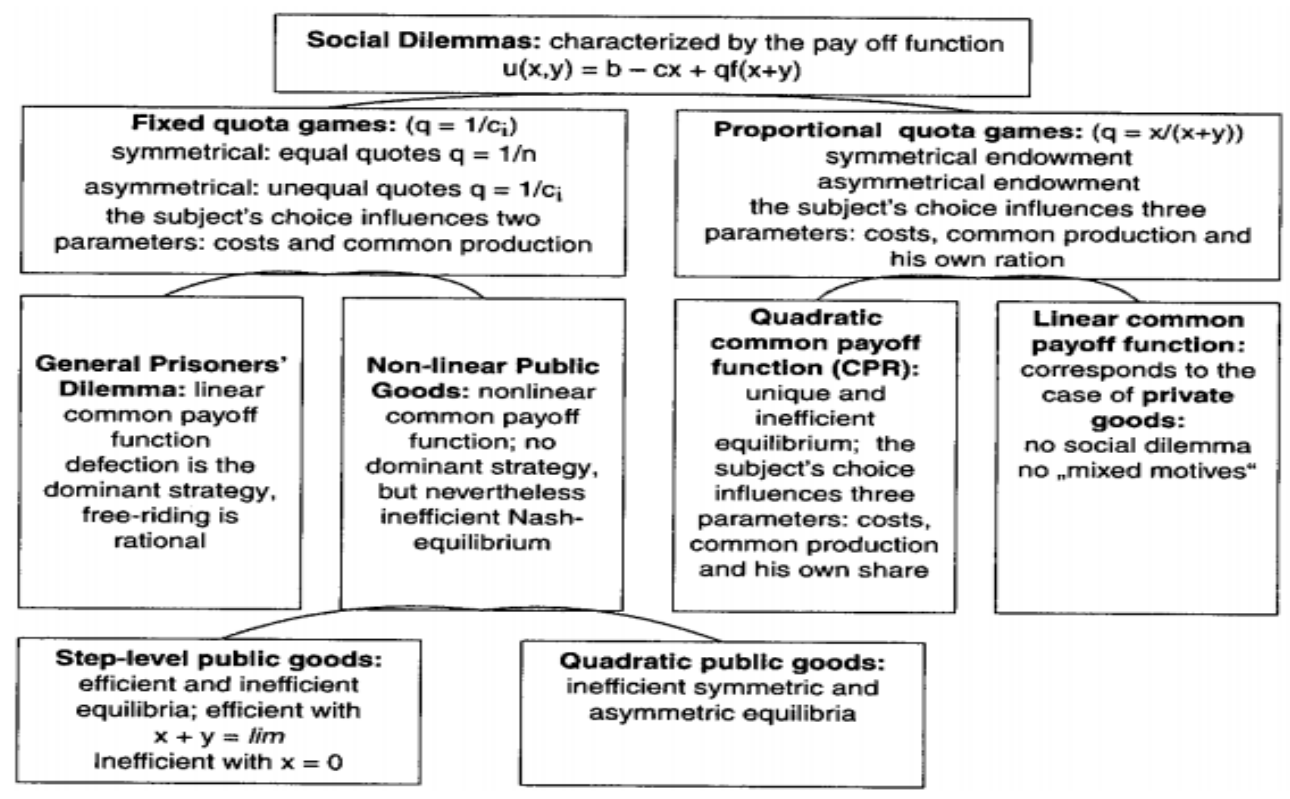

Gambar 2 Jenis dilema sosial

Sumber: Beckenkamp (2006)

Dilihat dari tren jurnal ilmiah 15 tahun terakhir yang membahas dilema sosial, penulis ditemukan adanya tiga kecenderungan perkembangan studi. Pertama adalah banyaknya studi yang melakukan penelitian dilema sosial antar kelompok. Studi-studi terawal tentang dilema sosial seperti dilema terdakwa dan tragedy of the common merupakan studi tentang dilema sosial yang dihadapi oleh individu dalam situasi interpersonal dan sebagai anggota kelompok. Namun demikian, penelitian telah 
menunjukkan bahwa adanya variabel identitas sosial telah memunculkan perilaku kerjasama dalam dilema sosial, namun efeknya terbatas demi keuntungan kelompok-dalam/in-group (Dawes \& Messick, 2000). Studi-studi ini telah berkembang ke arah dilema sosial antar kelompok, seperti dalam kasus perang dan perdamaian antar kelompok, mulai dari antar-kelompok kecil, antar-korporasi, sampai dengan antar-negara. Dalam buku Peace Psychology in Asia, misalnya, Montiel \& Noor (2009) kerap menggunakan kasus-kasus dilema sosial dalam penjelasan pemikirannya tentang konflik dan perdamaian antar-kelompok.

Kedua, studi-studi dilema sosial mulai lebih intensif menyentuh bidang ilmu yang lebih luas. Terminologi dilema sosial banyak dikenal dan digunakan tidak hanya dalam bidang ekonomi, yang sering dijadikan contoh dalam studi-studi awal dilema sosial, tetapi juga sudah merambah ke bidang politik, hukum, kebijakan publik, dan sebagainya. Misalnya, dalam artikelnya,Puzzling Lack of a Social Dilemma (2008), Hinffors mengkaji teori sosial dilema sebagai salah satu teori utama yang pesat mempengaruhi pembentukan kebijakan pemerintah. Ketiga, studi-studi tentang dilema sosial sudah mulai banyak meneliti peran afeksi atau emosi dalam pengambilan keputusan. Hertel \& Fiedler (1994), misalnya, dalam penelitian eksperimentalnya memeriksa efek dari suasana hati dan priming evaluatif terhadap kerjasama dalam permainan dilema sosial. Batson, Batson, Todd, Brummett, Shaw \& Aldeguer (1995) menulis sebuah artikel berjudul "Empathy and the collective good: caring for one of the others in a social dilemma". Apabila sebelumnya studi-studi tentang dilema sosial sangat kognitif-rasionalistik dan dingin, studi-studi dilema sosial dewasa ini mulai memberi tempat yang lebih luas bagi peran afeksi, emosi, dan suasana hati.

Studi-studi tentang dilema sosial seringkali menggunakan metode eksperimental dengan permainan yang dilangsungkan dalam laboratorium. Permainan eksperimental merupakan sebuah situasi di mana partisipan memilih antara alternatif kooperatif dan defektif/non-kooperatif, atau antara alternatif kontribusi (contributing, give some) dan mengambil (harvesting, take some), yang menghasilkan konsekuensi bagi diri mereka sendiri dan orang lain. Terdapat informasi matriks imbalan yang melukiskan hasil yang dapat diperoleh partisipan (misalnya, uang).

Menurut Rockenbach \& Wolff (2009), ada tiga generasi eksperimen dilema sosial. Pada eksperimen generasi pertama, partisipan disajikan dengan permainan yang sudah ditentukan (prespecified) yang penuh dengan berbagai aturan. Pada eksperimen generasi kedua, partisipan disajikan dua buah lingkungan yang berbeda, dan partisipan diminta untuk memilih salah satunya. Rockenbach dan Wolff mengembangkan eksperimen dilema sosial generasi ketiga, partisipan harus merancang dan meningkatkan mutu strateginya sendiri dalam permainan tertentu. Studi mereka merupakan studi pertama yang berusaha menjawab pertanyaan mengenai bagaimana orang membentuk lingkungan mereka untuk menyelesaikan dilema public good (benda/komoditas/layanan umum yang dapat diakses oleh semua orang) apabila orang diberikan diskresi penuh atas aturan permainan.

Hasil utama dari berbagai studi dilema sosial adalah bahwa terdapat sejumlah faktor yang menentukan apakah orang akan berkoorperasi atau defek dalam situasi dilema sosial. Faktor utama adalah struktur insentif. Selanjutnya, sejumlah faktor bersifat individual, seperti orientasi nilai (individualis/kompetitor/kooperator) dan derajat kepercayaan interpersonal; dan sejumlah faktor lagi bersifat kolektivistik (mengambil keputusan bukan sebagai individu tetapi sebagai anggota kelompok). Studi-studi tentang dilema sosial sangat bersandar pada paradigma behavioristik dan menggunakan eksperimen yang sangat terkontrol. Metode eksperimen ini kurang tepat digunakan sehingga temuantemuannya dalam taraf tertentu kurang meyakinkan. Eksperimen terkontrol kurang mempertimbangkan faktor ketidakpastian (uncertainty) karena semua insentif/imbalan (payoff) dilukiskan dengan sangat jelas dan terstruktur. Dalam kondisi seperti Indonesia sebagai negara kolektivistik, yang menurut riset-riset psikologi lintas budaya sangat tinggi toleransi terhadap ketidakpastian (uncertainty) dan menekankan interdependensi, maka generalisasi hasil studi-studi eksperimental tentang dilema sosial ini akan sangat terbatas. Ringkasnya, kultur dapat mempengaruhi persepsi dan interpretasi orang atas situasi dilema, serta aturan, norma, dan praktik apa yang akan 
diterapkan orang. Evaluasi lainnya adalah bahwa dilema sosial juga bersifat terikat-budaya. Suatu tingkah laku yang dianggap tepat dalam sebuah situasi pada sebuah kebudayaan mungkin dipandang tidak tepat dalam kultur yang lain. Sebagai contoh, kultur yang menekankan peningkatan diri (selfenhancement) berbeda pengaruhnya terhadap kecenderungan orang untuk berkoperasi dalam situasi dilema sosial bila dibandingkan dengan kultur yang menekankan transendensi diri.

Namun demikian, hal yang mengesankan dari teori dilema sosial ini adalah progresivitasnya dalam mencakup isu-isu baru dan mempertimbangkan faktor-faktor baru. Salah satu paradigma menarik tentang dilema sosial disampaikan oleh Ngan \& Au (2008). Mereka mengingatkan kita bahwa tidak hanya seringkali ada sejumlah besar orang membuat keputusan mereka dalam situasi dilema sosial, tetapi juga, dalam banyak contoh, orang-orang melakukannya dalam titik-titik waktu yang berbeda. Ngan \& Au menyampaikan adanya step-level public-good dilemma dalam hal mana keputusan dibuat dalam empat kondisi. Pertama, partisipan tidak memiliki informasi apa-apa mengenai keputusan orang lain. Kedua, partisipan diperbarui dengan informasi parsial. Ketiga, partisipan mengetahui jumlah orang yang memilih keputusan bersama, tetapi tidak mengetahui jumlah orang yang memilih keputusan pribadi; atau, partisipan mengetahui jumlah orang yang memilih keputusan pribadi tetapi tidak mengetahui jumlah orang yang memilih keputusan bersama. Keempat, partisipan diberikan informasi sepenuhnya. Dibandingkan dengan kondisi pertama, partisipan dalam kondisi kedua, ketiga, dan keempat menunda keputusan mereka. Jumlah kooperator (yang berkontribusi terhadap keputusan bersama) juga bervariasi antar kondisi. Ngan \& Au menjelaskan bagaimana kampanye untuk memecahkan problem sosial dapat mengambil manfaat dari informasi umpan balik. Hal ini dapat diperumit bila kita membedakan lagi antara umpan balik implisit dan umpan balik eksplisit.

Dalam era dewasa ini saat the social mengambil peran yang besar dalam ruang kehidupan publik dan privat (seperti ditandai oleh perkembangan pesat jejaring sosial seperti Facebook, YouTube, dan Twitter), maka studi-studi tentang dilema sosial, khususnya studi-studi pada awal perkembangan teori ini, menjadi memudar daya tariknya. Hal ini disebabkan karena studi-studi tersebut terlalu percaya diri mengasumsikan bahwa pengambilan keputusan dalam situasi dilema sosial utamanya didorong utamanya oleh konsen/perhatian terhadap konsekuensi. Nyatanya tidak demikian. Inilah kelemahan dari studi-studi dilema sosial. Variabel-variabel psikologi sosial lain, seperti interaksi sosial, pengaruh sosial, serta atribusi sosial, juga berpengaruh signifikan terhadap pilihan seseorang dalam situasi dilema sosial. Artinya adalah bahwa konteks sosial memainkan peran yang tidak boleh diabaikan dan hendaknya dipertimbangkan dalam perancangan maupun generalisasi hasil riset dilema sosial. Gifford (2008) juga menunjukkan faktor-faktor lain yang menentukan pengambilan keputusan dalam dilema sosial, yakni natur sumber daya (pengaruh geofisis), pengaruh tata kelola pemerintahan (governance) atau regulasi, relasi dengan pengambil keputusan yang lain, serta karakteristik dan motif pengambil keputusan itu sendiri; dengan catatan bahwa semua faktor tersebut dimediasikan oleh kesadaran akan dilema (dilemma awareness).

Kritik lainnya adalah bahwa studi-studi empiris tentang dilema sosial belum banyak menyelidiki perbedaan dilema sosial yang berskala lokal dan yang bersifat global. Kadangkala keputusan kooperasi atau defeksi memiliki efek lokal, misalnya, terhadap keberadaan kelompok atau terhadap komunitas lokal. Keputusan yang lain memiliki implikasi yang lebih luas dan memiliki efek yang mendunia, seperti keputusan dalam dilema sumber daya alam yang dapat berimplikasi pada iklim. Kebanyakan studi tentang keputusan dan tingkah laku dalam dilema sosial berasal dari eksperimen dan penelitian tentang dilema sumber daya umum lokal. Pertanyaan yang menantang dalam hal ini adalah: Sejauh manakah hasil studi tersebut dapat dijadikan prinsip teoretis yang dapat diaplikasikan pada dilema sosial skala global (misalnya perubahan iklim)?

Penelitian dilema sosial selanjutnya perlu mengambil objek-objek studi yang bersifat komparatif lintas tempat, lintas budaya, dan dilakukan dalam situasi sosial nyata. Misalnya, permasalahan psikologi transportasi sebagian dapat dipandang sebagai persoalan dilema sosial. 
Kemacetan parah di Jakarta, ibukota, dapat diteliti dengan kerangka teoretis dilema sosial; kemudian diperbandingkan dengan dilema sosial transportasi publik yang misalnya berhasil dikelola di BogotaKolombia. Contoh-contoh lainnya adalah dilema sukarelawan, dilema orang yang terstigmatisasi (karena penyakit, karena sejarah keanggotaan dalam kelompok tertentu), dan sebagainya. Bila memungkinkan, lakukan lebih banyak studi longitudinal, studi kualitatif, sebab studi-studi sebelumnya bersifat jangka pendek (short term). Sebagaimana kita ketahui bahwa tindakan seperti mengambil (harvesting) ikan sebanyak-banyaknya tidak akan kelihatan efeknya dalam jangka pendek, melainkan konsekuensinya baru akan kelihatan dalam jangka waktu panjang. Studi-studi yang tekun dan bersifat longitudinal dan historis diperlukan dalam kasus-kasus seperti ini.

Berdasarkan hal di atas, peneliti-peneliti lebih lanjut dapat menyusun klasifikasi dilema sosial yang bersifat sehari-hari, sebagai alternatif terhadap taksonomi Gambar 1 yang menggunakan istilahistilah matematis-ekonomis yang sangat teknis.

\section{PENUTUP}

Lewin (1951) pernah menyatakan bahwa tidak ada yang lebih praktis daripada sebuah teori yang baik (there is nothing so practical as a good theory). Sebuah uraian teoretis sebagaimana dilakukan dalam tulisan ini bukanlah minim kegunaan. Uraian ini dapat membantu akademisi dan praktisi untuk membangun dan mengembangkan teori (dan demikian juga: praktik) terbaik di lingkungan masing-masing. Dari kajian kritis di atas, dapat disimpulkan bahwa dengan berbagai kelebihan dan keterbatasannya, baik teori aktivitas maupun dilema sosial itu prospektif dalam hal merangsang riset khususnya untuk kasus-kasus di Indonesia, karena belum banyak yang melakukan penggarapan dengan menggunakan pisau analisis kedua teori tersebut.

\section{DAFTAR PUSTAKA}

Avis, J. (2007). Engeström's version of activity theory: A conservative praxis? Journal of Education and Work, 20(3), 161-177.

Bakhurst, D. (1991). Consciousness and revolution in Soviet philosophy. New York: Cambridge.

Batson, C. D., Batson, J. G., Todd, R. M., Brummett, B. H., Shaw, L. L., \& Aldeguer, M. R. (1995). Empathy and the collective good: caring for one of the others in a social dilemma. Journal of Personality And Social Psychology, 68(4), 619-631.

Beckenkamp, M. (2006). A Game Theoretic Taxonomy of Social Dilemmas, Central European Journal of Operations Research, (3), p1-17.

Bedny, G., \& Karwowski, W. (2004). Teori aktivitas as a basis for the study of work. Ergonomics, 37(2), 134-153.

Capra, F. (2002) Hidden connections: Integrating the biological, cognitive, and social dimensions of life into a science of sustainability. New York: Doubleday.

Cole, M., \& Engeström, Y. (1993). A cultural-historical approach to distributed cognition. Dalam G. Salomon (Ed.), Distributed cognitions. Cambridge, UK: Cambridge University Press.

Dawes, R. M., \& Messick, D. M. (2000). Social dilemmas. International Journal of Psychology, 35(2), 111-116. 
Engeström, Y. (1987). Learning by expanding: An activity-theoretical approach to developmental research. Helsinki, Finland: Orienta-Konsultit Oy.

Engeström, Y. (1999). Innovative learning in work teams: Analyzing cycles of knowledge creation in practice. Dalam Y. Engeström, R. Miettinen, \& R.-L. Punamäki (Eds.), Perspectives on teori aktivitas (h. 377-404). Cambridge, UK: Cambridge University Press.

Engestrom, Y. (2001) Expansive learning at work: toward an activity theoretical reconceptualization, Journal of Education and Work, 14(1), 133-156.

Engestrom, Y., \& Miettinen, R. (1999) Introduction. Dalam Y. Engestrom, R. Miettinen \& R. Punamaki (Eds). Perspectives on activity theory. New York: Cambridge University Press.

Gifford, R. (2008). Toward a comprehensive model of social dilemma. Dalam A. Biel, D. Eek, \& T. Gärling, New issues and paradigms in research on social dilemmas. New York: Springer Science and Business Media.

Håkansson, H., \& Prenkert, F. (2004). Exploring the exchange concept in marketing. Dalam H. Håkansson, D. Harrison, \& A. Waluszewski (Eds.), Rethinking marketing: Developing a new understanding of markets (h. 75-97). Chichester, UK: Wiley.

Hertel, G., \& Fiedler, K. (1994). Affective and cognitive influences in social dilemma game, European Journal of Social Psychology (24) 1, p131-145.

Hinnfors, J. (2008). Puzzling lack of a social dilemma. Scandinavian Political Studies, 31(1), 69-90.

James, W. (1890). The principles of psychology. New York: Holt.

Leontiev, A. N. (1977). Activity and consciousness. Dalam Philosophy in the USSR: Problems of dialectical materialism (h. 180-202). Moscow: Progress Publishers.

Lewin, K. (1951). Field theory in social science: Selected theoretical papers. New York, NY: Harper \& Row.

Montiel, C. J., \& Noor, N. M. (Eds.). (2009). Peace psychology in Asia. New York: Springer Science and Business Media.

Ngan, C. S., \& Au, W. T. (2008). Effect of information structure in a step-level public good dilemma under a real-time protocol. Dalam A. Biel, D. Eek, \& T. Gärling, New issues and paradigms in research on social dilemmas. New York: Springer Science and Business Media.

Penyeragaman yang menyusup. (2010, Agustus 27). Kompas.com. Diakses pada 3 Januari 2011, dari http://cetak.kompas.com/read/2010/08/27/03333315/penyeragaman.yang.menyusup

Rockenbach, B., \& Wolff, I. (2009). Institution design in social dilemmas: How to design if you must? Diakses pada 3 Januari 2011, dari http://mpra.ub.unimuenchen.de/16922/1/MPRA_paper_16922.pdf

Sarwono, S. W. (2005). Psikologi kelompok dan psikologi terapan. Jakarta: Balai Pustaka.

Toulmin, S. (1999). Knowledge as shared procedures, in: Y. Engestrom, R. Miettinen \& R. Punamaki (Eds.). Perspectives on activity theory. New York: Cambridge University Press. 
Van Oers, B., Elbers, E., van der Veer, R., Wardekker, W. (Eds.). (2008). The transformation of learning: Perspectives from activity theory. Cambridge: Cambridge University Press.

Virkkunen, J., \& Kuutti, K. (2000). Understanding organizational learning by focusing on "activity systems.” Accounting Management and Information Technologies, 10, 291-319.

Vygotsky, L. (1978). Mind in society: the development of higher psychological processes. Cambridge, MA: Harvard University Press/Cambridge University Press.

Weiten, W. (1989). Psychology: Themes and variations. Pacific Grove, CA: Brooks Cole. 